\title{
ALAT TRANSPORTASI KASULTANAN NGAYOGYAKARTA HADININGRAT DALAM PERSPEKTIF INTEGRASI STRUKTURAL
}

\author{
Indro Baskoro Miko Putro *)
}

\begin{abstract}
ABSTRACK
The means of transport belonging to the palace of Yogyakarta Sultanate is treated as an heirloom that gets legitimacy sultan as Kagungan Dalem (the king) in accordance habits within the palace. Royal heirlooms, including transportation and the name has a certain degree of corresponding 'proximity' to the sultan. Heirloom that has been used or is still used by the Sultan and was named Kyai masculine, while the feminine was named Nyai. If the vehicle is a major heirloom, then in front of Kyai or Nyai title is added to the title Kanjeng.

Palace as the creator of "symbols", his actions are not solely based on the interpretation of freedom as well as his own accord, but in pursuance of a stimulus interpretation for the creation of a public servant interpretation response Ngayogyakarta palace. The existence of the palace transportation, must be addressed by society as a symbol of the greatness of Yogyakarta Yogyakarta Sultanate dynasties that have stood the test of time, proven to date is revitalized through rituals jamasan Kanjeng heritage train Nyai amulets and train companion Sura month, the exhibition train palace Mulud every month, and the procession procession procession procession jumenengan sultan and the palace wedding reception using the train.
\end{abstract}

Keywords: transportasi, Kasultanan Ngayogyakarta Hadiningrat, Integrasi Struktural

\begin{abstract}
ABSTRAKSI
Alat-alat transportasi milik keraton Kasultanan Yogyakarta diperlakukan sebagai pusaka yang mendapat legitimasi sultan sebagai Kagungan Dalem (milik raja) sesuai kebiasaan dilingkungan keraton. Benda-benda pusaka keraton, termasuk alat transportasi mempunyai nama dan gelar tertentu sesuai 'kedekatannya' dengan sultan. Pusaka yang pernah digunakan atau masih digunakan oleh sultan dan bersifat maskulin diberi gelar Kyai, sedangkan yang bersifat feminin diberi gelar Nyai. Apabila kendaraan tersebut merupakan pusaka utama, maka didepan gelar Kyai atau Nyai tersebut akan ditambahkan gelar Kanjeng.

Keraton sebagai pencipta "simbol-simbol", tindakannya tidak semata-mata berdasarkan pada interpretasi kebebasan maupun kemauannya sendiri, namun dalam kerangka memberikan stimulus interpretasi bagi terciptanya respon interpretasi dari masyarakat kawula keraton Ngayogyakarta Hadiningrat. Keberadaan alat transportasi keraton tersebut, tentunya akan ditanggapi oleh masyarakat Yogyakarta sebagai simbol kebesaran dinasti Kasultanan Yogyakarta yang tidak lekang oleh waktu, terbukti sampai saat ini masih direvitalisasi melalui upacara-upacara ritual jamasan pusaka kereta Kanjeng Nyai Jimat dan kereta pendampingnya dibulan Sura, pameran kereta keraton setiap bulan Mulud, dan prosesi arak-arakan kirab jumenengan sultan maupun kirab resepsi pernikahan menggunakan kereta keraton.
\end{abstract}

\footnotetext{
* Indro Baskoro Miko Putro (indro_bmp@yahoo.com), Staf Pengajar Program Studi Kriya Seni, Jurusan Kriya, Fakultas Seni Rupa, Institut Seni Indonesia Yogyakarta
} 
Kata Kunci: transportasi, Kasultanan Ngayogyakarta Hadiningrat, Integrasi Struktural

\section{PENDAHULUAN}

Menurut Susan K. Langer, seni adalah simbol representasi sehingga seni bukan sekedar mengacu pada meaning (makna), namun lebih pada import value (nilai pesan) yang ingin dibawakan. Untuk memahami pengertian tersebut, penulis mencoba mengangkat topik alat transportasi yang dimiliki dan digunakan keraton Kasultanan Ngayogyakarta.Alat transportasiyang penulis maksudkan dalam kajian ini merupakan sarana pemindahan manusia atau barang dari satu tempat ke tempat lainnya, menggunakan kendaraan yang digerakkan oleh manusia atau mesin yang digunakan keraton Kasultanan Ngayogyakarta dalam aktivitas sehari-hari. Adapun sebagai sarana eksplorasi, elaborasi dan mengkajinya digunakan paradigma Integrasi Struktural.

\section{Landasan Teori}

Perspektif Integrasi Struktural merupakan salah satu Pendekatan
Struktural yang berguna untuk membuka penelitian suatu fenomena kebudayaan dalam hubungan relasional antara unsurunsurnya atau dengan kata lain merupakan pendekatan yang berfungsi mengurai objek kajian penelitian. Oleh karena itu untuk mempertajam analisis, biasanya pendekatan Integrasi Struktural dibantu pendekatan yang lain, misalnya: Fungsionalisme Struktural, Interaksionisme Simbolik, Teori Aksi dan lain sebagainya.

Sesuai rumusan Pendekatan Integrasi Struktural, analisis dimulai dengan mengurai objek penelitian dari pokok budaya kemudian berangsur-angsur menyempit menuju bagian-bagiannya yang lebih khusus.Analisis dimulai dari culture (ranah budayanya), dilanjutkan institution (lembaga), kemudian complex (inti permasalahan), lalu traits (unit, ciri atau sifat) dan diakhiri dengan item (unsur, hal, barang atau spesifikasi). Adapun skematika langkah kerjanya adalah sebagai berikut:

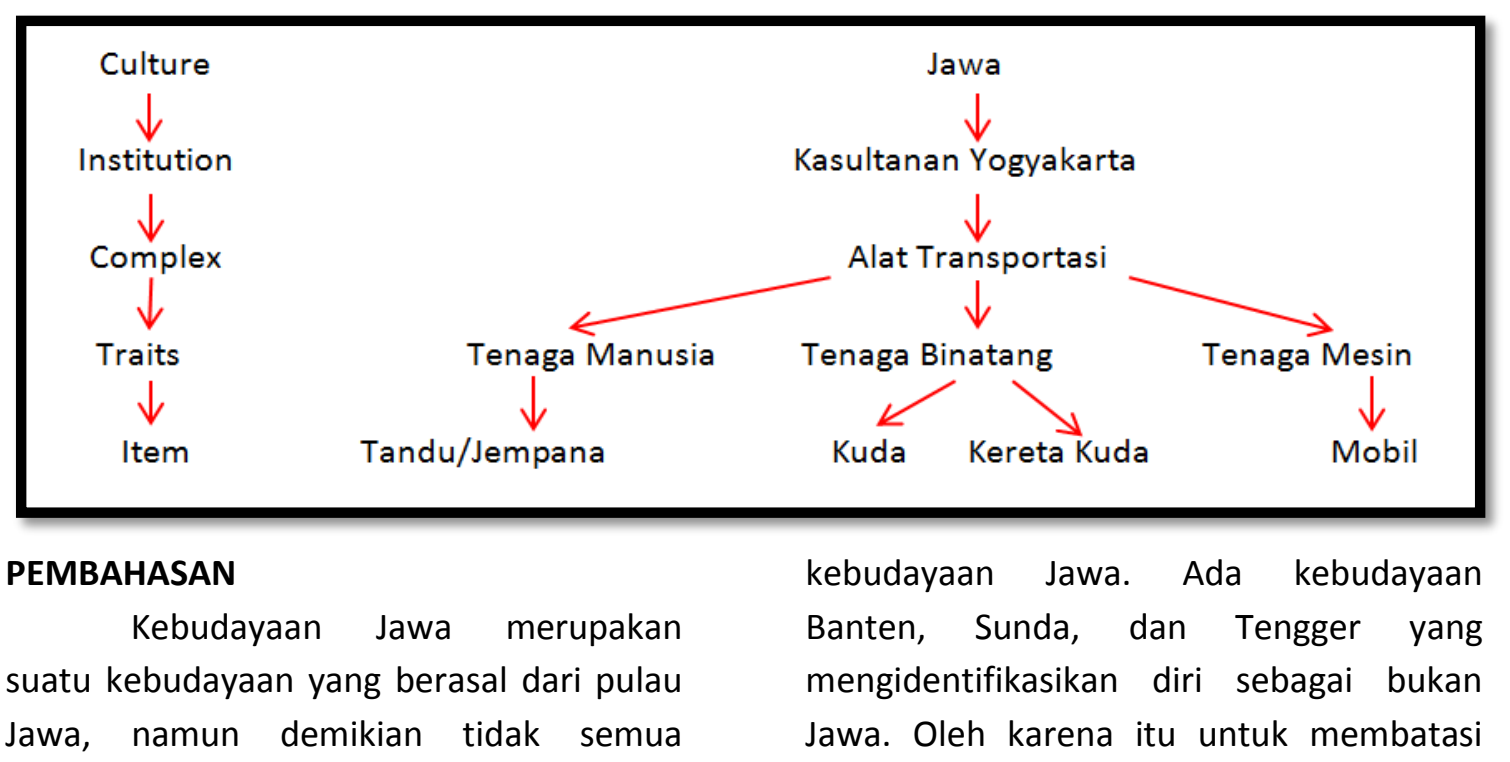

kebudayaan yang ada di Jawa adalah 
pembahasan, maka dipilihlah Kasultanan Yogyakarta sebagai institusinya.

Kasultanan Yogyakarta merupakan bagian dari kerajaan Mataram Islam yang terbagi akibat Palihan Nagari pada tahun 1755 M menjadi dua sesuai perjanjian Giyanti, yaitu: Kasunanan Surakarta dan Kasultanan Yogyakarta.' Kasunanan Surakarta berada di sebelah Timur, sedangkan Kasultanan Yogyakarta berada di sebelah Barat dengan wilayah kedua kerajaan yang tersebar dalam enclaveenclave (kantong-kantong wilayah) yang didiami sejumlah cacah sebagaimana tertera dalam perjanjian Giyanti. ${ }^{\text {i. }}$

Pembagian kerajaan Mataram Islam menjadi dua ini menimbulkan ekses yang berkepanjangan hingga saat ini, walaupun seringkali tidak disadari. Konsekuensi nyata dari konflik tersebut muncul secara halus dalam wujud kebudayaan. Masing-masing kerajaan mengidentifikasikan diri sebagai keraton yang lebih 'Mataram' dibandingkan yang lain dan membangun identitas yang berbeda atau bisa dikatakan bahwa keduanya bersaing secara diam-diam. Wujud dari persaingan ini teraktualisasi dalam bentuk dan gaya yang berbeda antara Kasunanan Surakarta dan Kasultanan Yogyakarta dalam hal berbahasa, berpakaian dan berkesenian ${ }^{\mathrm{iii}}$ termasuk seni tari, wayang kulit, wayang wong, keris, gamelan, batik, ukiran, ragam hias, dan lain sebagainya.

Pada kesempatan ini, penulis memilih alat transportasi sebagai salah satu kompeks kebudayaan Jawa yang ada di keraton Yogyakarta. Alat transportasi merupakan salah satu ikon kebudayaan yang unik untuk dikaji, karena relevansinya dalam kehidupan manusia masih berlangsung hingga saat ini. Apalagi bila alat transportasi tersebut merupakan koleksi keraton Kasultanan Ngayogyakarta Hadiningrat, yang pada masanya merupakan kendaraan dinas raja dan keluarga kerajaan, maka pembahasannya akan menjadi lebih menarik.

Untuk memudahkan pembahasan, maka penulis mengategorikan alat transportasi keraton Kasultanan Ngayogyakarta Hadiningrat sesuai tenaga yang digunakan. Ada yang bertenaga manusia seperti tandu, bertenaga kuda seperti kereta kuda dan kuda itu sendiri, serta yang bertenaga mesin dan paling modern adalah mobil. Dari semua kendaraan keraton Yogyakarta itu, barangkali yang paling penting dan legendaris adalah kereta kuda, karena dalam acara-acara penting kerajaan dari mulai kirab jumenengan, pernikahan, sampai membawa jenazah raja ke peristirahatannya yang terakhir di makam Imogiri digunakan kereta kuda. Namun demikian, karena semua alat transportasi keraton itu tidak hanya mengemban fungsi praktis sebagai kendaraan tetapi juga dianggap memiliki kekuatan magis sebagai pusaka peninggalan keramat, maka keempat moda transportasi itu akan dibahas satu per satu.

Alat-alat transportasi milik keraton Kasultanan Yogyakarta diperlakukan sebagai pusaka yang mendapat legitimasi sultan sebagai Kagungan Dalem (milik raja) sesuai kebiasaan dilingkungan keraton. Perlakuan terhadap pusaka ini memiliki peraturan yang khas keraton, sehingga penggunaan maupun pewarisannya diatur dalam lembaga keraton yang terdiri dari 
sultan dan keluarganya, termasuk keluarga besarnya yang disebut trah dan pejabat maupun pegawai kerajaan. Orang diluar keraton dapat dikatakan sulit untuk mengaksesnya.

Benda-benda pusaka keraton, termasuk alat transportasi mempunyai nama dan gelar tertentu sesuai 'kedekatannya' dengan sultan. Pusaka yang pernah digunakan atau masih digunakan oleh sultan dan bersifat maskulin diberi gelar Kyai, sedangkan yang bersifat feminin diberi gelar Nyai. Apabila kendaraan tersebut merupakan pusaka utama, maka didepan gelar Kyai atau Nyai tersebut akan ditambahkan gelar Kanjeng. ${ }^{\text {iv }}$

Menurut sejarah alat transportasi umat manusia yang pertama menggunakan tenaga manusia untuk mengusungnya. Alat transportasi tersebut berupa tandu yang diangkat dan diusung oleh minimal dua orang, satu didepan dan satu dibelakang. Tandu merupakan alat transportasi jarak dekat yang digunakan keraton Yogyakarta. Ada tiga macam bentuk tandu di keraton Yogyakarta sesuai peruntukkannya. Pertama berbentuk wadah kotak tanpa tutup dengan sedikit hiasan yang biasa digunakan untuk membawa makanan dan sesaji upacara. Kedua berupa kursi tanpa hiasan yang digunakan untuk kendaraan dalam kegiatan harian. Ketiga berupa rumah-rumahan dengan banyak ornamen dan hiasan digunakan untuk upacara dan pesta. Ketiga macam tandu ini mempunyai nama masing-masing sesuai kegunaannya. Jolen merupakan alat untuk mengangkut sesaji dan benda-benda sakral berbentuk wadah kotak tanpa tutup, sedangkan kremun adalah alat untuk mengangkut pakaian dan asesories kraton yang berbentuk rumah-rumahan. Untuk mengangkut orang terdapat dua macam alat, yang pertama disebut tandu, berbentuk kursi tanpa hiasan yang digunakan sehari-hari. Contohnya: adalah tandu Kanjeng Kyai Tandu Lawak. Sedangkan yang kedua sering disebut joli jempana, berbentuk rumah-rumahan dengan hiasan yang indah yang digunakan untuk mengantar putri raja saat menjadi pengantin atau bepergian. ${ }^{v}$

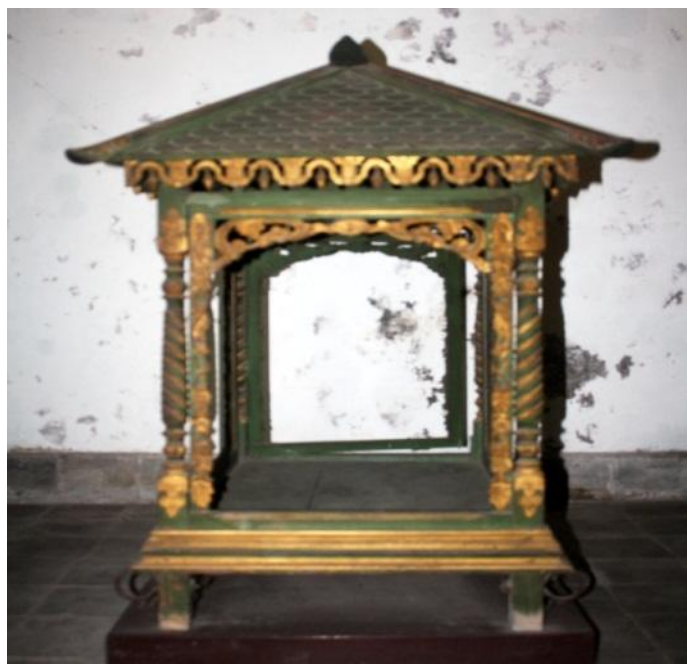

Gambar 1. Jolen kraton Yogyakarta.

Dokumentasi penulis

Penulis mendapatkan kesulitan dalam melacak keberadaan tandu keraton Yogyakarta karena sangat sedikit data yang didapat disebabkan banyak jempana atau tandu yang rusak akibat tertimpa bangunan yang rubuh, sehingga tidak dapat dilihat dan diamati. ${ }^{\text {vi }}$ Namun demikian dari keterangan beberapa abdi dalem keraton didapatkan penjelasan bahwa sebelum gempa tersebut, terdapat 36 buah jempana milik keraton Yogyakarta. 


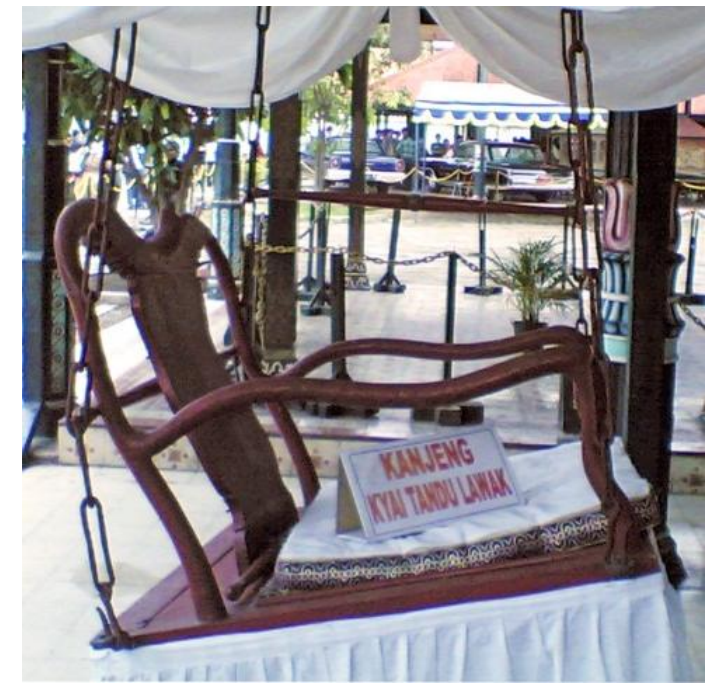

Gambar 2. Kanjeng Kyai Tandu Lawak, kraton Yogyakarta. Dokumentasi penulis.

Salah satu tandu tertua dan paling keramat di keraton Yogyakarta adalah sebuah tandu berupa kursi yang dikenal sebagai Kanjeng Kyai Tandu Lawak, yang merupakan peninggalan Sultan Hamengku Buwono I. Tandu ini diusung oleh empat orang, dua didepan dan dua dibelakang dengan masing-masing orang disisi kanan dan kiri tandu. Kanjeng Kyai Tandu Lawak merupakan kendaraan harian Sultan Hamengku Buwono I untuk menginspeksi keratonnya dengan cara ditandu berkeliling diatas dinding benteng keraton melewati lima plengkung (sekarang tinggal dua) dan keempat bastion benteng (sekarang tinggal tiga).

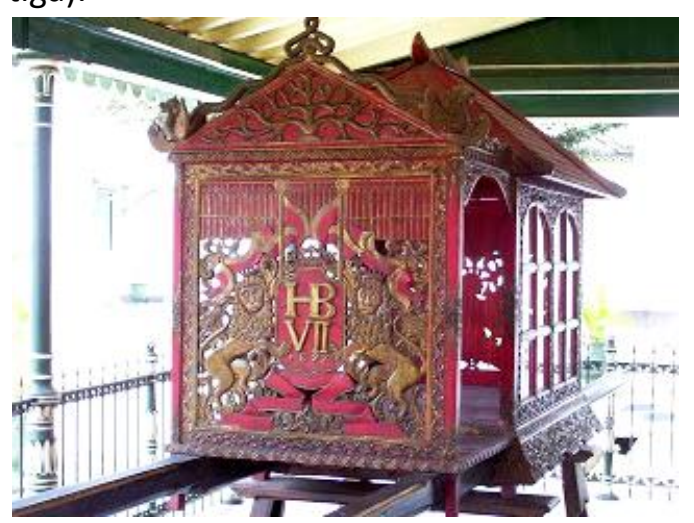

Gambar 3. Joli Jempana. kraton Yogyakarta. Dokumentasi penulis.
Selain itu masih ada beberapa tandu yang diingat oleh abdi dalem keraton, seperti: tandu Kyai Kudus, Kyai Purbonegoro, dan Kyai Wegono Putro. Tandu-tandu ini bervariasi penampilan dan kegunaannya, namun kebanyakan joli jempana digunakan oleh para putri raja, sedangkan kaum laki-laki lebih banyak menunggang kuda. Pada upacara pernikahan sebelum masa HB VIII, pengantin perempuan ditandu sedangkan pengantin laki-laki naik kuda. Oleh karena itu tandu untuk pengantin putri biasanya dibuat sangat indah, berbentuk rumahrumahan dengan begitu banyak ornamen dan biasanya dihiasi motif garuda, naga atau singa, serta diusung 16 orang abdi dalem yang bertubuh kekar.

Alat transportasi kedua yang demikian penting bagi umat manusia adalah kuda. Sejarah penjinakan dan penggunaan kuda sebagai alat transportasi dimulai di Asia Tengah sekitar 6000 tahun sebelum Masehi. Domestikasi kuda tersebut kemudian diikuti dengan penemuan roda oleh orang-orang Babilonia sekitar 3000 tahun sebelum Masehi. Semenjak penemuan roda inilah perkembangan alat transportasi menjadi pesat hingga saat ini. Mungkin pula karena begitu pentingnya kuda dalam kehidupan manusia, sehingga ukuran kekuatan mesin pun sampai saat ini masih menggunakan satuan tenaga kuda. vii

Penggunaan kuda sebagai alat transportasi di Jawa baru dikenal pada abad ke-14. Hal ini berdasarkan dari sumber tertulis tertua yang berhasil penulis dapatkan, menyatakan bahwa pada masa Majapahit penggunaan kuda hanya terbatas sebagai hewan tunggangan, 
belum menjadi hewan penghela kereta. Pada masa itu untuk menarik gerobak digunakan gajah, kerbau maupun lembu sebagaimana disebutkan dalam naskah Negarakertagama karya empu Prapanca, pupuh XVII sampai dengan pupuh LX yang menceritakan perjalanan baginda Rajasanagara menuju Lumajang. viii

Pada masa itu barangkali masyarakat Jawa masih beranggapan bahwa hewan yang besar seperti gajah dan kerbau lebih kuat, sehingga dijadikan hewan penarik kereta. Sementara kuda masih terbatas sebagai hewan tunggangan di kala perang, berpergian maupun berburu. Namun demikian sebagai binatang kelangenan, kuda mendapatkan posisi yang penting dalam kebudayaan Jawa. Indikasinya adalah pandangan bahwa kesempurnaan seorang laki-laki Jawa didapatkan setelah dirinya memiliki turangga (kuda), curiga (keris), wanita (istri), wisma (rumah) dan kukila (burung).

Keberadaan kuda di tanah Jawa dapat diketahui dari tulisan Tjakradibrata, yang menjelaskan bahwa pada mulanya di pulau jawa terdapat kuda berbadan kecil yang sering disebut kuda Pony. Untuk memperbaiki mutu kuda Jawa, maka banyak dilakukan perkawinan silang dengan kuda-kuda dari pulau Sumba, Sawo, dan Rotte yang dikenal sebagai kuda Sandelhout, sehingga kemudian tidak ada lagi kuda Jawa yang sejati. Apalagi setelah orang-orang Belanda banyak memasukkan kuda-kuda dari luar seperti kuda Arab dan Australia ke pulau Jawa. ${ }^{i x}$

Selain itu, adanya buku primbon tentang kuda menunjukkan demikian pentingnya kuda dalam khasanah budaya Jawa. Sebuah primbon berbahasa Jawa karangan R. Tanojo dengan lugas menguraikan segala hal tentang kuda secara menyeluruh. Pembahasan katuranggan kuda tentang bentuk, warna, proporsi dan unyeng-unyeng kuda yang berhubungan dengan sifat-sifat kuda yang pantas dipilih menjadi kuda tunggangan, kuda peliharaan dan sahabat, sampai halhal mengenai umur kuda, cara perawatan kuda, hari pasaran yang baik untuk membeli kuda dan cara mendidik kuda terdapat dalam buku ini. ${ }^{x}$

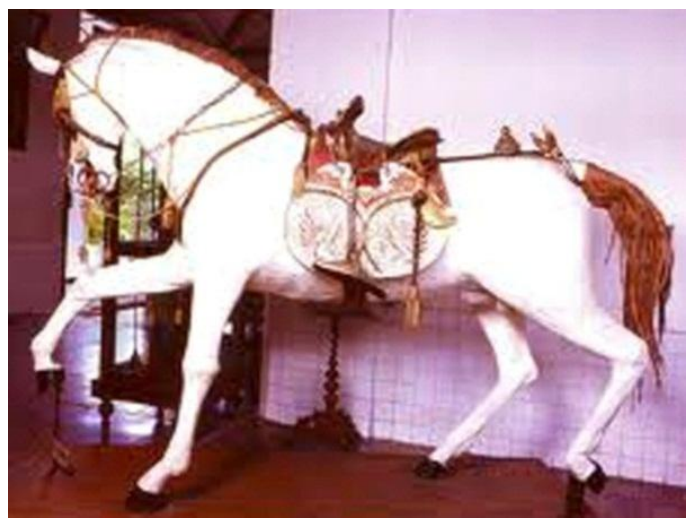

Gambar 4. Pelana kanjeng Kyai Cekathak Dokumentasi penulis.

Pentingnya kuda sebagai alat transportasi bagi keraton Yogyakarta terlihat dari pusaka Kanjeng Kyai Cekathak, yang berupa pelana dan seperangkat tali kekang kuda peninggalan Sultan Hamengku Buwono I. Kita perlu ingat bahwa sultan HB I merupakan penunggang kuda hebat yang memperjuangkan tahtanya dengan memimpin pasukan kavaleri berkuda yang cukup tangguh. Walaupun sekarang keraton tidak lagi memiliki kuda-kuda tunggangan, namun melalui foto-foto masa lalu dan peninggalan istal-istal kudanya dapatlah kita bayangkan kualitas dan banyaknya kuda keraton Yogyakarta pada masa jayanya. Dulu istal kuda tunggangan keraton berada diantara plataran Kedaton 
dengan Kasatriyan dan keraton Kilen sekarang. ${ }^{\mathrm{i}}$

Kuda sebagai penarik kereta baru dikenal di Jawa pada akhir abad ke-18, terutama setelah perjanjian Giyanti 1755 M. Dapat dipahami bahwa masuknya kereta yang ditarik kuda ke dalam alat transportasi keraton merupakan wujud pengaruh persinggungan kebudayaan dengan budaya Eropa khususnya VOC. Pada zamannya kereta kuda merupakan alat transportasi penting bagi masyarakat, tak terkecuali Keraton Yogyakarta. Keraton Yogyakarta memiliki 23 kereta kuda bermacam jenis, mulai dari kereta untuk bersantai dalam acara non-formal sampai kereta kebesaran yang digunakan secara resmi oleh sultan. Kereta kebesaran atau yang lebih dikenal sebagai kereta kencana tersebut ibaratnya seperti mobil kenegaraan berplat nomor polisi RI 1 yang berfungsi sebagai kendaraan dinas bagi presiden Republik Indonesia.

Kanjeng Nyai Jimat merupakan kereta kebesaran Sultan HB I sampai dengan Sultan HB IV. Kereta kuda ini merupakan pemberian Gubernur Jenderal Jacob Mossel dan merupakan kereta terkeramat milik keraton Yogyakarta. Hal ini terlihat pada saat upacara jamasan pusaka milik keraton setiap bulan Suro, kereta ini selalu dimandikan dengan salah satu kereta lain yang digilir sebagai pendampingnya. Kereta kencana (karena berwarna emas) Kanjeng Nyai Jimat, saat ini sudah tidak lagi digunakan karena tuanya, sebagai penggantinya adalah kereta Kyai Garudha Yaksa. ${ }^{\text {xi }}$

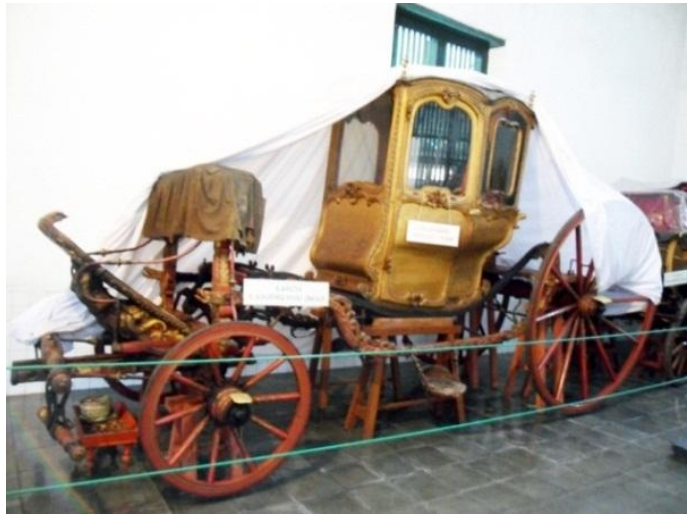

Gambar 5. Kereta Kencana Kanjeng Nyai Jimat. Dokumentasi penulis.

Kereta Kyai Garudha Yaksa merupakan kereta kebesaran Sultan HB VI sampai HB $X$, walaupun dalam kenyataannya Sultan HB IX dan HB X sudah menggunakan mobil. Kereta kuda buatan Den Haag tahun 1861 ini terakhir kali digunakan pada tahun 1989, pada saat prosesi Kirab Jumenengan Dalem (upacara pemahkotaan raja) Sri Sultan Hamengku Buwono X.

Kereta Kanjeng Kyai Wimono Putro adalah kereta yang digunakan oleh Pangeran Adipati Anom (Putra Mahkota), sedangkan kereta Kanjeng Kyai Jatayu merupakan kendaraan yang digunakan sultan untuk menghadiri acara semi resmi. Kereta Roto Praloyo merupakan kereta jenazah yang hanya digunakan untuk membawa jenazah sultan. Konon kereta ini baru digunakan dua kali, yaitu: pada saat pemakaman Sultan HB VIII dan HB IX. 


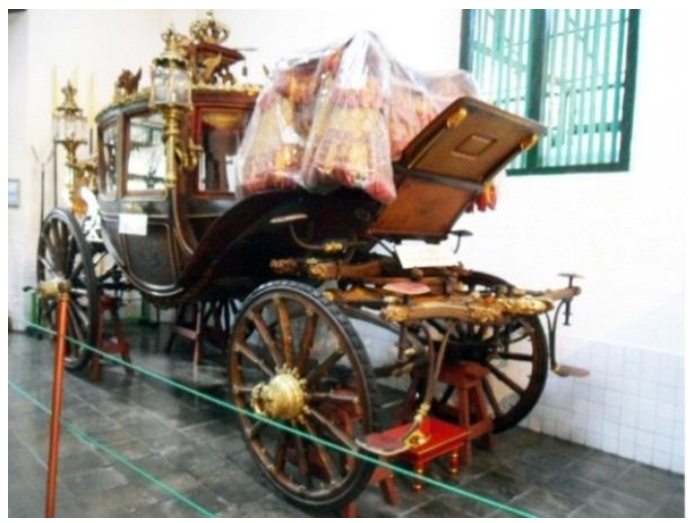

Gambar 6. Kereta Kyai Garudha Yaksa. Dokumentasi penulis.

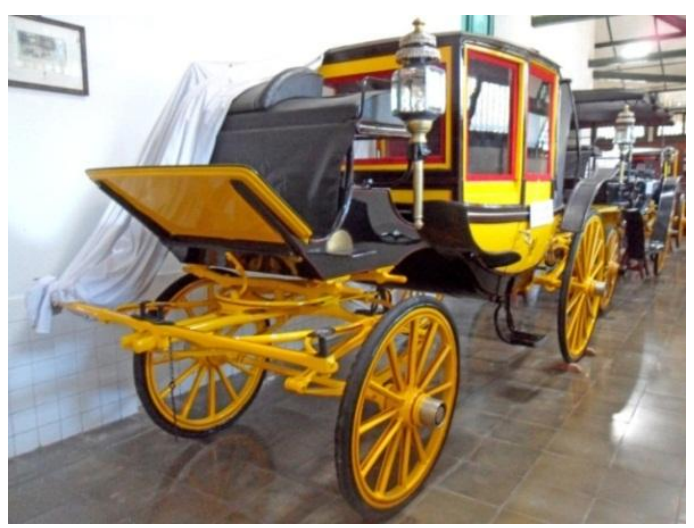

Gambar 7. Kereta Kyai Landower Ngabean.

Dokumentasi penulis.

Kereta Kyai Harsunaba, buatan Belanda 1870 dan kereta Kyai Jongwiyat adalah kendaraan yang digunakan dalam resepsi pernikahan putra putri sultan, sementara untuk plesir terdapat kereta Kyai Manik Retno buatan Belanda 1815, Kyai Jaladara dan Kyai Mondro Juwolo. Selain itu juga terdapat kereta Kyai Noto Puro, Kyai Roto Biru, Kyai Kutha Kaharjo, Kyai Puspoko Manik, Kyai Rejo Pawoko, Premili, Kapulitin, Landower Surabaya, Landower Wisman, Kyai Landower Ngabean, Landower, Kus Gading dan Kus nomor 10. Tidak semua kereta keraton Yogyakarta bergelar kyai, tergantung pada tingkatannya.

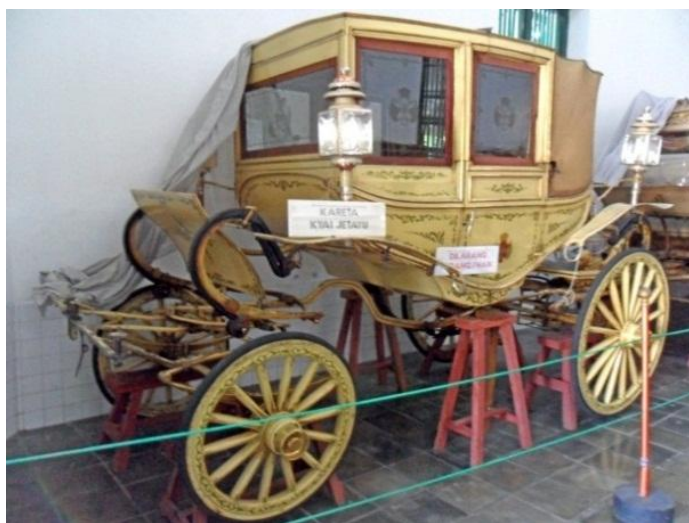

Gambar 9. Kereta Kyai Jatayu. Dokumentasi penulis.

Kebanyakan kereta kuda adalah buatan Eropa terutama Negeri Belanda walaupun ada beberapa yang dibuat di Rotowijayan, misalnya: kereta Kanjeng Kyai Jatayu yang dibuat pada tahun 1930. Selain dipesan dari Eropa, ada beberapa kereta yang dibuat di wilayah Yogyakarta. Hal ini terlihat dari kesederhanaan model kereta yang menyerupai bentuk andong yang digunakan masyarakat umum sekarang ini. Dari data beberapa kereta yang dibuat di Jawa, diketahui bahwa pengerjaannya dilakukan oleh ahli-ahli pembuat kereta dari Cina, walaupun supervisor-nya tetap orang Belanda. Jadi pada beberapa kereta Kasultanan Yogyakarta, dijumpai perpaduan budaya antara Barat dan Jawa yang sangat kuat.

Alat transportasi ketiga milik keraton Yogyakarta adalah kendaraan bertenaga mesin dan berbahan bakar bensin. Khusus kendaraan mobil ini baru digunakan dan dimiliki oleh Sultan Hamengku Buwono IX dan HB X. Mobil Cadilac berwarna hitam dengan plat nomor Indonesia 2 merupakan kendaraan dinas Sri Sultan Hamengku Buwono IX, sewaktu menjabat Wakil Presiden Republik Indonesia pada tahun 1973-1978. 


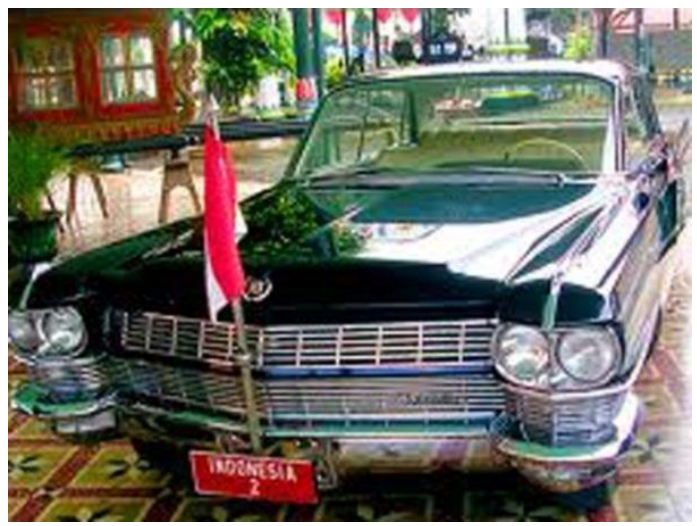

Gambar 9. Mobil Cadilac HB IX sewaktu menjabat Wakil Presiden RI. Dokumentasi penulis.

\section{PENUTUP}

Demikianlah yang dapat penulis kemukakan berkaitan dengan alat-alat transportasi milik keraton Ngayogyakarta Hadiningrat, mulai dari jempana (tandu), kuda, kereta kuda dan mobil. Penulis dapat menyimpulkan dari keempat moda transportasi yang dimiliki dan digunakan keraton Yogyakarta tersebut, kesemuanya tidak hanya bermakna namun lebih lanjut memiliki nilai pesan yang ingin disampaikan pada khalayak, bahwa jempana (tandu), kuda, kereta kuda dan mobil tersebut bukan sekedar kendaraan sebagai alat transportasi semata, namun merupakan simbol yang menunjukkan siapa pemilik dan pemakainya, yang tidak lain adalah sultan Ngayogyakarta Hadiningrat dan keluarganya. Kebesaran dan kemewahan tampak pada setiap alat transportasi keraton tersebut, terlebih pada kendaraan yang digunakan, pernah digunakan dan disukai oleh sultan yang ditandai dengan nama dan gelarnya Kagungan Dalem Kanjeng Kyai atau Nyai tergantung dari sifat pembawaannya.

Keraton sebagai pencipta "simbolsimbol", tindakannya tidak semata-mata berdasarkan pada interpretasi kebebasan maupun kemauannya sendiri, namun dalam kerangka memberikan stimulus interpretasi bagi terciptanya respon interpretasi dari masyarakat kawula keraton Ngayogyakarta

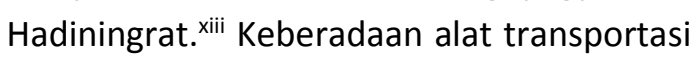
keraton tersebut, tentunya akan ditanggapi oleh masyarakat Yogyakarta sebagai simbol kebesaran dinasti Kasultanan Yogyakarta yang tidak lekang oleh waktu, terbukti sampai saat ini masih direvitalisasi melalui upacara-upacara ritual jamasan pusaka kereta Kanjeng Nyai Jimat dan kereta pendampingnya dibulan Sura, pameran kereta keraton setiap bulan Mulud, dan prosesi arak-arakan kirab jumenengan sultan maupun kirab resepsi pernikahan menggunakan kereta keraton, seperti yang baru saja dilangsungkan pada bulan Oktober 2013 yang lalu.

\section{DAFTAR PUSTAKA}

Behrend, T., Kraton and Cosmos in Tradisional Java, Paris : Archipel, No.37, 1989.

Darmosugito, "Apakah Sebabnja B.P.H. Mangkubumi Diam-diam Meninggalkan Surakarta" dalam Kota Jogjakarta 200 Tahun 7 Oktober 1756-7 Oktober 1956, Yogyakarta: Panitya Peringatan Kota Jogjakarta 200 Tahun, 7 Oktober 1956.

Darsiti Soeratman, Kehidupan Dunia Keraton Surakarta, 1830-1939, Yogyakarta: Yayasan Untuk Indonesia, 2000.

Houben, Vincent J.H., Keraton dan Kompeni: Surakarta dan Yogyakarta, 1830-1870 Yogyakarta: Bentang, 2002.

Muljana, Slamet, Menuju Puncak Kemegahan Sejarah Kerajaan 
Majapahit, Yogyakarta: P.T. LKIS Pelangi Aksara, 2005.

Ricklefs, M.C., Yogyakarta di Bawah Sultan Mangkubumi, 1749-1792: Sejarah Pembagian Jawa, Yogyakarta: Mata Bangsa, 2002.

Soekanto, Sekitar Jogjakarta 1755-1825 (Perjanjian Gianti-Perang Diponegara), Jakarta: Penerbit Mahabarata, 1952.

Sumandiyo Hadi, Y., Seni dalam Ritual Agama, Yogyakarta: Penerbit Buku Pustaka bekerja sama dengan Lembaga Penelitian ISI Yogyakarta, Januari 2006.

Pertunjukan dan Masyarakat Penonton, Yogyakarta: BP ISI Yogyakarta, 2012.

S. Margana, Kraton Surakarta dan Yogyakarta 1769-1874 Yogyakarta: Pustaka Pelajar, 2004.

Tanojo, R., Primbon Prekutut, Gemak, Jago, Kutjing lan Jaran, Tangguhe, Tjandrane lan Jamune, Surabaya: Trimurti, tanpa tahun.

Tjakradibrata, Kitab Pengetahuan dari Hal Koeda, Weltevreden: Balai Poestaka, 1922.

van Den Berg, H.J. dan I.P. Simandjoentak, Panggung Sejarah Dunia jilid 1 dan 2, Groningen-Djakarta: J.B. Wolters, 1954.

\section{Daftar Wawancara}

Djatmiko, R., abdi dalem keraton Yogyakarta, 7 Nopember 2013, pukul 11.00-12.15 WIB.

Rahayuningsiwi, V., Sekretaris Pribadi Sri Sultan Hamengku Buwono IX di keraton Kilen, kompleks keraton Yogyakarta, 9 Nopember 2013, pukul 15.30-16.30 WIB.

Roto Prasetyo, abdi dalem keraton Yogyakarta, Rotowijayan, 7
Nopember 2013, pukul 15.00-16.00 WIB.

Soetjipto Atmosungkowo, abdi dalem keraton Yogyakarta, 8 Nopember 2013, pukul 08.00-09.35 WIB.

\section{Sumber Internet}

ullensentanu.com/detail/news.php?id=68 id.wikipedia.org/Keraton_Ngayogyakarta_ Hadiningrat

CATATAN:

'Ricklefs, M.C., Yogyakarta di Bawah Sultan Mangkubumi, 1749-1792: Sejarah Pembagian Jawa, Yogyakarta: Mata Bangsa, 2002, pp. 107-155. Lihat juga Soekanto, Sekitar Jogjakarta 1755-1825 (Perjanjian GiantiPerang Diponegara), Jakarta: Penerbit Mahabarata, 1952 dan S. Margana, Kraton Surakarta dan Yogyakarta 17691874 Yogyakarta: Pustaka Pelajar, 2004.

iiDarmosugito, "Apakah Sebabnja B.P.H. Mangkubumi Diam-diam Meninggalkan Surakarta" dalam Kota Jogyakarta 200 Tahun 7 Oktober 1756-7 Oktober 1956, Yogyakarta: Panitya Peringatan Kota Jogjakarta 200 Tahun, 7 Oktober 1956, pp. 11-12.

iiisumandiyo Hadi, Y., Seni dalam Ritual Agama, Yogyakarta: Penerbit Buku Pustaka, Januari 2006, p.48.

iv Wawancara dengan R. Djatmiko, abdi dalem keraton Yogyakarta, 7 Nopember 2013, pukul 11.00-12.15 WIB.

"Wawancara dengan Soetjipto Atmosungkowo, abdi dalem keraton Yogyakarta, 8 Nopember 2013, pukul 08.00-09.35 WIB.

viBangsal Traju Mas tempat menyimpan jempana keraton Yogyakarta rubuh karena gempa bumi yang melanda Yogyakarta pada 27 Mei 2006, menyebabkan banyak tandu mengalami kerusakan.

viivan Den Berg, H.J. dan I.P. Simandjoentak, Panggung Sejarah Dunia jilid 1 dan 2, Groningen-Djakarta: J.B. Wolters, 1954

viiiMuljana, Slamet, Menuju Puncak Kemegahan Sejarah Kerajaan Majapahit, Yogyakarta: P.T. LKIS Pelangi Aksara, 2005, p. 42.

ixTjakradibrata, Kitab Pengetahuan dari hal Koeda, Weltevreden: Balai Poestaka, 1922.

xTanojo, R., Primbon Prekutut, Gemak, Jago, Kutjing lan Jaran, Tangguhe, Tjandrane lan Jamune, Surabaya: Trimurti, tanpa tahun.

xiWawancara dengan V. Rahayuningsiwi, Sekretaris Pribadi Sri Sultan Hamengku Buwono IX di keraton Yogyakarta, 9 Nopember 2013, pukul 15.30-16.30 WIB.

xiiWawancara dengan Roto Prasetyo, abdi dalem keraton Yogyakarta, Rotowijayan, 7 Nopember 2013, pukul 15.00-16.00 WIB.

xiiiSumandiyo Hadi, Y., Seni Pertunjukan dan Masyarakat Penonton, Yogyakarta: BP ISI Yogyakarta, 2012, pp.104-109. 